Research Report No. 4/2013

\title{
Do Lenders Make Effective Regulators? An Assessment of the Equator Principles on Project Finance
}

Douglas Sarro

Follow this and additional works at: http://digitalcommons.osgoode.yorku.ca/clpe

\section{Recommended Citation}

Sarro, Douglas, "Do Lenders Make Effective Regulators? An Assessment of the Equator Principles on Project Finance" (2013). Comparative Research in Law \& Political Economy. Research Paper No. 4/2013.

http://digitalcommons.osgoode.yorku.ca/clpe/253 


\section{OSGOODE}

OSGOODE HALL LAW SCHOOL YOR K U N I VERSITY

\section{OSGOODE HALL LAW SCHOOL}

Comparative Research in Law \& Political Economy

RESEARCH PAPER SERIES

Research Paper No. 4/2013

Do Lenders Make Effective Regulators? An Assessment of the Equator Principles on Project Finance

Douglas Sarro

\section{Editors:}

Peer Zumbansen (Osgoode Hall Law School, Toronto, Director Comparative Research in Law and Political Economy)

John W. Cioffi (University of California at Riverside)

Leeanne Footman (Osgoode Hall Law School, Toronto, Production Editor)

Comparative Research in Law \& Political Economy 


\title{
Articles
}

\section{Do Lenders Make Effective Regulators? An Assessment of the Equator Principles on Project Finance."}

\author{
By Douglas Sarro**
}

\section{A. Introduction}

Over the past decade and a half, private sector actors have developed innumerable environmental and social standards whose stated intention is to further global public interests, such as sustainable development in less developed countries (LDCs). While some authors have welcomed these standards as a means of addressing transnational problems that governments are ill-equipped to deal with, ${ }^{1}$ others argue that these standards often amount to little more than a public relations exercise, with private actors producing highminded standards on paper but failing to enforce them in practice. $^{2}$

* This article is based on a presentation at the Fifth CLPE conference made at Osgoode Hall Law School Toronto, 12 March 2012, entitled "Transnational Private Regulatory Governance: Regimes, Dialogue, Constitutionalization."

** J.D. Candidate, Osgoode Hall Law School. I would like to thank Peer Zumbansen and Poonam Puri for their guidance and feedback on several previous drafts of this article. I would also like to thank the other CLPE Conference participants for their questions and comments and Fahad Siddiqui for his feedback on a previous draft of this article. All errors and omissions are my own. Email: DouglasSarro@osgoode.yorku.ca.

\footnotetext{
${ }^{1}$ See e.g., Michael Vandenbergh, The New Wal-Mart Effect: The Rule of Private Contracting in Global Governance, 54 UCLA L. REV. 913, 919 (2007) ("although private environmental contracting is potentially deeply problematic, it may be the only viable means to fill important gaps in the regulatory regime"); David Vogel, The Private Regulation of Global Corporate Conduct: Achievements and Limitations, 49 BUS. \& SOCIETY 68, 80 (2010) ("By creating new expectations of global corporate conduct and by establishing new regulatory institutions to address them, civil regulations have thus partially reduced the governance deficits and regulatory failures that characterize many global firms and markets"). This view is compatible with the view that public regulation remains a necessary element in addressing transnational problems. See e.g., John Ruggie, Taking the Embedded Liberalism Global: The Corporate Connection, in EMBEDDING GLOBAL MARKETS: AN ENDURING CHALLENGE 231, 232 (John Ruggie ed., 2008) ("the corporate sector, which has done more than any other to create the growing gaps between global economies and national communities, is being pulled into playing a bridging role between them. In the process, a global public domain is emerging, which cannot substitute for effective action by states but may help produce it").
}

${ }^{2}$ See e.g., Thomas McInerney, Putting Regulation Before Responsibility, 40 CORNELL INT'L. L.J. 171, 199-200 (2007) ("While the coercive power monopolized by state regulatory authorities has its limitations, it also has many benefits which must not be understated. It is at great peril that we cede these responsibilities to untested 
Rather than making general arguments about the effectiveness of private standards (that is, their ability to affect the behavior of actors in a way that supports their stated goals), ${ }^{3}$ this article looks at the effectiveness of a specific standard: the Equator Principles on project finance. The Equator Principles were developed in 2003 by a group of major financial institutions and are intended to ensure that the large infrastructure projects these institutions finance, especially those located in LDCs, are built and operated in an environmentally and socially responsible manner.

An assessment of lenders' ability to regulate their borrowers' projects via the Equator Principles may shed light on the general debate over the effectiveness of private standards. ${ }^{4}$ Such an assessment is also timely, as the Equator Principles are currently being revised, ${ }^{5}$ in part to respond to criticisms that they have not been effective. ${ }^{6}$

Rather than making a holistic assessment of lenders' effectiveness as regulators, this article looks at lenders' effectiveness in carrying out each of three tasks commonly associated

methods [i.e., private regulation] that intuition, analysis, and experience suggest are bound to fail"); Terry Collingsworth, Corporate Social Responsibility, Unmasked, 16 ST. THOMAS L. REV. 669, 670-71 (2004) ("The already questionable idea of trusting corporations to self-police compliance with their broad codes of conduct is rendered ridiculous, given the aggressive refusal of these same companies to accept being bound to the minimal constraints of ATCA [the U.S. Alien Tort Claims Act, 28 U.S.C. section 1350]"). For a critique aimed at a more general audience, see ROBERT REICH, SUPERCAPITALISM: THE TRANSFORMATION OF BUSINESS, DEMOCRACY, AND EVERYDAY LIFE 170 (2007) ("Corporations that have signed codes of conduct promising good behavior appear to have taken important steps toward social responsibility, but the pressures operating on them to lure and keep investors haven't eased one bit. In supercapitalism, they cannot be socially responsible, at least not to any significant extent" [emphasis in original]).

${ }^{3}$ See Kal Raustiala, Compliance \& Effectiveness in International Regulatory Cooperation, 32 CASE W. RES. J. INT'L. L. 387, 392-93 (2000).

\footnotetext{
${ }^{4}$ This article does not address the second regulatory relationship to which the Equator Principles give rise: a selfregulatory relationship between lenders by which they commit to negotiate the substance of the Equator Principles into loan agreements and attempt to enforce them. See infra note 61 and accompanying text.
}

\footnotetext{
${ }^{5}$ Press Release, Equator Principles, Draft of updated Equator Principles (EP III) released for stakeholder consultation and public comment (13 August 2012), available at: http://www.equator-principles.com (last accessed: 1 December 2012). See also Oliver Balch, Sustainable finance: how far have the Equator Principles gone? THE GUARDIAN, 15 November 2012, available at: http://www.guardian.co.uk/sustainablebusiness/sustainable-finance-equator-principles (last accessed: 1 December 2012).
}

${ }^{6}$ See infra notes 50-52 and accompanying text. 
with regulation - standard setting, monitoring, and enforcement ${ }^{7}$ - and asks whether other current or potential environmental regulators, such as governments, intergovernmental organizations (IGO), or non-governmental organizations (NGOs), are better placed to carry out these tasks.

This article argues that lenders, owing to their expertise in the project finance sector and their understanding of existing norms on managing environmental and social risk, reflected in their reliance on these norms as models for the Equator Principles, are relatively wellplaced to set effective standards and to effectively monitor their borrowers' conduct. It also argues, however, that lenders are currently not well-placed to enforce the Equator Principles. Their short-term interest in the completion of the projects they finance impairs their ability to credibly threaten to withdraw financing in the face of persistent noncompliance by borrowers. This flaw, however, is not fatal - it could be addressed by implementing reforms long suggested by NGOs and authors, including delegating some of lenders' enforcement responsibilities to an ombudsperson and requiring project companies to fund technical assistance to government regulators to empower them to enforce state-level regulatory frameworks. ${ }^{8}$

Section B of this article summarizes the Equator Principles and places them in context by briefly describing the project finance industry that they are intended to regulate, how the Equator Principles came to be adopted, and key criticisms leveled against the Equator Principles since their adoption. Section C evaluates lenders' ability to (I) set standards, (II) monitor compliance, and (III) enforce the Equator Principles relative to other actors.

\section{B. Project Finance and its Discontents}

Project finance is a means of mobilizing private capital to build infrastructure projects, such as natural resource extraction projects and electricity generation projects. A project is executed by a project company, generally a special purpose entity ${ }^{9}$ created by one or more

\footnotetext{
7 See Christopher Hood, Henry Rothstein, \& Robert BaldWin, The Government of Risk: Understanding Risk REGULATION REGIMES 24-28 (2001); Colin Scott, Regulating Everything: From mega- to meta-regulation, 60 ADMINISTRATION 61, 67-68 (2012).

${ }^{8}$ See infra notes $150-51$ and accompanying text.

${ }^{9}$ A special purpose entity, or SPE (also known as a special purpose vehicle, or SPV) is a business organization, typically but not always a corporation, whose business is limited to a specific purpose. They are often used as a means of insulating their creators, which are often also business organizations, from liability for the business that the special purpose entity undertakes. See EdWARD YeSCOMBE, PRINCIPLES OF PROJECT FINANCE section 2.2 (2002).
} 
project sponsors for the sole purpose of implementing the project. The project sponsors hold equity in the project company, but the project company's main source of finance is debt. The project sponsors, generally with the help of a financial advisor, seek debt financing from one or more lenders. ${ }^{10}$

Unlike traditional finance, where loans are made on the basis of the borrower's existing assets and credit rating, project finance loans are made on the basis of the expected value of a project - a project that may not be completed on time, or at all. This creates considerable risk for lenders, which they seek to mitigate by carrying out extensive due diligence and by closely monitoring the project's development. ${ }^{11}$

Through much of the mid-to-late twentieth century in the West, the risks associated with the construction of large infrastructure projects were borne by governments, which built and operated these projects through government-owned enterprises. Beginning in the 1980s, however, these governments came to adopt the view, rooted in neoclassical economics, that the best way to spur economic growth would be to shrink the size of government to make room for private entrepreneurship and innovation. To this end, governments began to stop using public funds to pay for projects and instead contracted private companies to build and operate them with private financing. ${ }^{12}$

This approach filtered into the international arena, where the World Bank increasingly encouraged LDC borrowers to use project finance to develop infrastructure. ${ }^{13}$ Financing for these projects came largely from export credit agencies run by developed country governments, the World Bank and its private lending arm, the International Finance Corporation (IFC), along with commercial banks. ${ }^{14}$

NGOs focused on human rights and environmental advocacy drew public attention to several projects funded by these lenders that, in their view, provided a means for private

\footnotetext{
${ }^{10}$ Id. at sections $4.1,4.3,5.1-5.2$.

${ }^{11}$ Id. at section 8.2

${ }^{12} / d$. at section 2.1.

${ }^{13}$ Philippe Benoit, Project Finance at the World Bank: An Overview of Policies and Instruments (World Bank Technical Paper No. 312, January 1996), available at: http://www.worldbank.org (last accessed: 1 December 2012).

${ }^{14}$ YESCOMBE, supra note 9, at sections 5.1, 11.3, 11.6.
} 
enterprise to reap significant profits by taking advantage of lax environmental and labor standards in LDCs. ${ }^{15}$ One of their central targets in the early to mid-1990s was the Three Gorges Dam, a hydroelectric power generation project sponsored by the Chinese government. ${ }^{16}$ It had been projected that the dam would flood $560 \mathrm{~km}$ (350 miles) of river canyon and displace 1.3 million people, but the Chinese government had no clear plan in place to address these effects. ${ }^{17}$ NGOs' first major victory came in 1995, when the Clinton White House instructed the U.S. export credit agency to decline to finance the dam. ${ }^{18}$ The World Bank also distanced itself from the project. ${ }^{19}$

NGOs soon turned their attention to the commercial banks that subsequently committed to finance the project, targeting several major banks for "naming and shaming" campaigns. ${ }^{20}$ Banks financing other projects posing significant environmental social risks, such as the Chad-Cameroon oil pipeline, were also targeted. ${ }^{21}$ Bank officials, fearing the effect these campaigns would have on their employers' reputations, were quick to respond

${ }^{15}$ Kirk Herbertson \& David Hunter, Emerging Standards for Sustainable Finance of the Energy Sector, 7 SUSTAINABLE DEV. L. \& POL'Y 5, 6 (2006).

${ }^{16}$ John Conley \& Cynthia Williams, Global Banks as Global Sustainability Regulators?: The Equator Principles, $33 \mathrm{~L}$. \& POL'Y 1, 2 (2011).

${ }^{17}$ See Paul Lewis, Export Agency Likely to Deny China Dam Aid, N.Y. TIMES, 14 October 1995, at 1; International Rivers Network \& Human Rights in China, Major Problems Found in Three Gorges Settlement Program (1998), available at: http://www.hrichina.org (last accessed: 1 December 2012).

${ }^{18}$ Lewis, id.

${ }^{19}$ Shai Oster, Reservoir of Fear: In China, New Risks Emerge at Giant Three Gorges Dam, WALL ST. J., 29 August 2007, at A.1.

${ }^{20}$ Andrew Hardenbrook, The Equator Principles: The Private Financial Sector's Attempt at Environmental Responsibility, 40 VAND. J. TRANSNAT'L L. 197, 205-206. The Rainforest Action Network's four year naming and shaming campaign against Citigroup has been cited as "[o]ne of the most documented and successful advocacy campaigns" of this period. See Niamh O'Sullivan \& Brendan O'Dwyer, Stakeholder perspectives on a financial sector legitimation process: The case of NGOs and the Equator Principles, 22 Acct., AUDIT'G \& AccounTAB. J. 553, 562 (2009). See also Heiko Spitzek, Innovation and Learning by Public Discourse: Citigroup and the Rainforest Action Network, (Working Paper No. 36, Center for Responsible Business, University of California, Berkeley, 2007).

${ }^{21}$ Richardson credits the campaign against the Chad-Cameroon pipeline as being "the specific catalyst" for the NGO pressure that led to the adoption of the Equator Principles. Benjamin Richardson, Financing Sustainability: The New Transnational Governance of Socially Responsible Investment, 17 YB. INT'L ENV. L. 73, 89 (2006). 
to NGOs' concerns. ${ }^{22}$ They initially adopted single-firm and single-issue environmental sustainability policies; in October 2002, representatives of nine commercial banks, joined by representatives of the IFC, met in London to discuss a more coordinated response. ${ }^{23}$

Their efforts culminated in the adoption of the Equator Principles in June 2003. Since then, the number of lenders that have adopted the Equator Principles (called Equator Principles Financial Institutions, or EPFIs) has grown from 10 to 73. The Equator Principles are overseen by an Association whose membership includes all EPFIs; operational issues are managed by a Secretariat. ${ }^{24}$ The Equator Principles were revised in 2006 (producing "EP II"), and, as noted in Section A, a second revision process is currently underway.

As part of this process, on 13 August 2012 the Equator Principles Association released a draft of the revised version of the Equator Principles ("Draft EP III") for comment. ${ }^{25}$ Below, I summarize Draft EP III, highlighting differences between Draft EP III and EP || (which remains in force) where these differences are significant.

Draft EP III, like its predecessors, operates by adding to the environmental due diligence and monitoring activities that lenders carry out as a matter of course. ${ }^{26}$ It applies to project

${ }^{22}$ Conley \& Williams, supra note 16 , at 17-18. See also O'Sullivan \& O'Dwyer, supra note 20, at 464 (noting that NGO leaders also tended to believe their campaigns were a primary cause of financial institutions' adoption of environmental and social standards); Christopher Wright \& Alexis Rwabizambuga, Institutional Pressures, Corporate Reputation, and Voluntary Codes of Conduct: An Examination of Equator Principles, 111 BUS. \& Soc. REV. $89,109-10$ (2006) (noting that financial institutions that are more vulnerable to being targeted by NGOs - largely due to their location in major Western city centres - were more likely to adopt and implement the Equator Principles).

${ }^{23}$ History of the Equator Principles, EQUATOR PRINCIPLES, http://www.equator-principles.com (last visited 4 September 2012); Frederick R. Anderson, Private Banks as Agents of Environmental Protection: The Equator Principles, Metro. CoRP. Couns., May 2004, 13 at 13, available at: http://www.metrocorpcounsel.com (last accessed: 1 December 2012).

24 The Equator Principles Association - Governance and Management, EQUATOR PRINCIPLES, available at: http://www.equator-principles.com/index.php/about-ep/about-ep/governance-and-management (last accessed: 1 December 2012).

25 Equator Principles, OfFicial FIRSt Draft OF EP III (13 August 2012), available at: http://www.equatorprinciples.com (last accessed: 1 December 2012) [hereinafter "Draft EP III"]. The comment period closed on 12 October 2012.

\footnotetext{
${ }^{26}$ As the preamble to Draft EP III notes, the Equator Principles are "intended to serve as a common baseline and framework for the implementation of each EPFI's internal environmental and social policies, procedures and standards related to its financing of Projects." Id. at Preamble.
} 
finance and advisory services where total project capital costs total US\$10 million or more, along with project-related corporate loans and bridge loans that meet certain additional thresholds. ${ }^{27}$

The Preamble to Draft EP III appears to offer dual justifications for mitigating the environmental and social risks posed by projects. It states that risk mitigation will achieve "improved financial ... outcomes" for lenders, but it also implies that risk mitigation efforts are part of a general obligation on the part of lenders to act responsibly and in accordance with social norms, reflected in international law and other emerging standards. ${ }^{28}$ The central pledge made by EPFls can also be found in the Preamble: "[w]e will not provide Project related loans and Project Finance Advisory services ... [that fit the criteria mentioned above] to Projects where the borrower will not, or is unable to comply with, the Equator Principles." 29

The first seven Equator Principles outline due diligence obligations to be completed prior to the signing of a loan agreement. Under Principle 1, lenders commit to review project proposals submitted by prospective borrowers and categorize them according to standards developed by the IFC for measuring the environmental and social risks posed by proposed projects. Projects falling under Category A (posing "significant adverse" risk) and Category $B$ (posing "limited" risk) are singled out for further review. ${ }^{30}$

Under Principle 2, the lender will begin this review process by requiring the prospective borrower to conduct an "adequate, accurate and objective" assessment (the "Assessment") of the project's risks and "propose measures to prevent, mitigate and manage" these risks. ${ }^{31}$ Principle 3 sets out the standards used to measure these risks.

\footnotetext{
${ }^{27}$ Draft EP III would apply to "Project-Related Corporate Loans" where "i. the loan is related to a single Project, ii. the total aggregate loan amount is at least US\$100 million, iii. the EPFI's individual Initial Exposure is at least US\$50 million, iv. the loan tenor is at least two years, and v. the borrower has Effective Operational Control (either direct or indirect) over the Project," along with "Bridge Loans with a tenor of less than two years that are intended to be refinanced by a Project Finance or Project-Related Corporate Loan." Id. at Scope statement. EP II does not apply to bridge loans or project-related corporate loans. EQUATOR PRINCIPLES, at Scope statement (2006), available at: http://www.equator-principles.com (last accessed: 1 December 2012) [hereinafter “EP II"].

${ }^{28}$ Id. at Preamble.

${ }^{29}$ Id.

${ }^{30} / d$. at Principle 1.

${ }^{31} / d$. at Principle 2.
} 
Projects in High Income OECD countries ${ }^{32}$ are assessed in accordance with local law, and are exempt from Principles 2 and $4-6 .{ }^{33}$ All other projects are assessed with reference to the IFC Performance Standards ${ }^{34}$ and Environmental, Health and Safety Guidelines ${ }^{35}$ in addition to local law. ${ }^{36}$

Under Principle 4, the lender will require the borrower, working from the findings and recommendations made in the Assessment, to prepare (1) an Environmental and Social Management Plan (ESMP) setting out measures the borrower will take to ensure compliance with the applicable standards, and (2) an Environmental and Social Management System (ESMS), which describes how the borrower will monitor for additional risks over the course of the project. If the lender concludes that the ESMP does not establish compliance with the applicable standards, the lender and the borrower are to agree to additional mitigating measures laid out in an Action Plan (AP). ${ }^{37}$

\footnotetext{
32 "High Income OECD Countries" are countries that are members of the Organization for Economic Cooperation and Development (OECD) that are designated as High-Income by the World Bank Development Indicators Database. Id. at Exhibit I - Glossary of Terms.
}

\footnotetext{
${ }^{33}$ Id. at Principle 3. EP II does not provide an exemption from Principle 2 for such projects. EP II, supra note 27, at
} Principle 3.

\begin{abstract}
${ }^{34}$ IFC, PeRformanCE StANDARDS AND GUIDANCE NOtes (2012), available at: www.ifc.org/performancestandards (last accessed: 1 December 2012. There are eight performance standards: (1) Assessment and Management of Environmental and Social Risks and Impacts, (2) Labor and Working Conditions, (3) Resource Efficiency and Pollution Prevention, (4) Community Health, Safety, and Security, (5) Land Acquisition and Involuntary Resettlement, (6) Biodiversity Conservation and Sustainable Management of Living Natural Resources, (7) Indigenous Peoples, and (8) Cultural Heritage).
\end{abstract}

35 IFC, EnVIRONmental, Health ANd SAfety Guidelines (2007), available at: http://www.ifc.org (last accessed: 1 December 2012, the Guidelines include general guidelines that apply to all projects, e.g., with regard to energy conservation, occupational hazards, community emergency preparedness, and construction and decommissioning, and specific industry sector guidelines, e.g., for mining, offshore oil and gas development, and pulp and paper mills).

${ }^{36}$ Draft EP III, supra note 25, at Principle 3.

${ }^{37}$ Id. at Principle 4. But see EP II, supra note 27, at Principle 4 (Under EP II, the borrower was required only to develop an $A P$, and the lender was not explicitly authorized to recommend additional mitigation measures if it found the AP insufficient). 
Principles 5-7 outline additional due diligence processes to be carried out for Category A and, "as appropriate," Category B projects. Principle 5 states that the lender will require the borrower to "demonstrate effective Stakeholder Engagement" with communities within a project's area of influence ("Affected Communities") and, where appropriate, "Other Stakeholders," such as NGOs and local governments, ${ }^{38}$ before construction commences. ${ }^{39}$ Additional standards apply where a project will affect Indigenous Peoples, equivalent to the protections afforded to them under other international and transnational standards. ${ }^{40}$ Under Principle 6, the lender will require the borrower to "establish a grievance mechanism designed to receive and facilitate resolution of concerns and grievances about the Project's environmental and social performance." Principle 7 states that the lender will retain an independent environmental expert to carry out an independent review of the borrower's compliance with the Equator Principles.

Principle 8 describes terms that the lender and borrower are to include in the loan agreement after due diligence is complete. The borrower must covenant to comply "in all material respects" with host country laws, the ESMP and the AP (if one has been prepared), and to report at least annually on its compliance with these standards. ${ }^{41}$ Where the borrower does not comply with these covenants, the lender will "work with the borrower ... to bring the Project back into compliance to the extent feasible," or, if such efforts do not succeed "within an agreed grace period," the lender may "exercise remedies." 42

\footnotetext{
38 This process of "Stakeholder Engagement" entails disclosure by the borrower of "the Assessment documentation and the ESMP ... to the public in the relevant local language and in a culturally appropriate manner." This process must also be "free from external manipulation, interference, coercion and intimidation." See Draft EP III, id. at Principle 5.

${ }^{39}$ See Draft EP III, id. at Principle 10.

${ }^{40}$ Compare EP II, supra note 27, at Principle 5 (which states that the borrower is required to conduct a "free, informed, and prior consultation" process); Draft EP III, id. at Principle 5 (which, drawing from the UN Declaration on the Rights of Indigenous Peoples, infra note 91, requires the borrower to establish Indigenous Peoples' 'free, prior and informed consent" to a project).

${ }^{41}$ Draft EP III, id. at Principle 8.

${ }^{42} / d$. at Principle 9.
} 
Principle 9 imposes an ongoing requirement on the lender to, for Category A projects and, "as appropriate," Category B projects, retain experts ${ }^{43}$ to verify the monitoring information it supplies to lenders. ${ }^{44}$

Principle 10 addresses public disclosure by borrowers and lenders. EP II states only that lenders would make annual disclosure of "transactions screened and closed, and about its Equator Principles implementation processes and experience, taking into account appropriate confidentiality considerations." ${ }^{45}$ Draft EP III would expand these obligations and create new reporting obligations applying for borrowers, including an obligation to disclose the Assessment, ESMP, and documentation of stakeholder engagement on the borrower's website. ${ }^{46}$

The Draft EP III seems aimed at rekindling some of the enthusiasm that had greeted the release of the first iteration of the Equator Principles in 2003. For instance, one commentator had expressed hope that the Equator Principles would signal "the dawn of a New Enlightenment based on responsible banking and fiduciary or sustainable capitalism. ${ }^{47}$ The NGOs that authored the Collevecchio Principles, ${ }^{48}$ a set of environmental and social guidelines for financial institutions released in January 2003 (six months before the Equator Principles were adopted), also "applaud[ed]" the Equator Principles, calling

\footnotetext{
${ }^{43}$ The lender must retain either an "Independent Environmental and Social Consultant," defined as "a qualified independent firm or consultant (not directly tied to the borrower) acceptable to the EPFI," or other "qualified and experienced external experts." See id. at Principle 9, Exhibit I - Glossary of Terms.
}

\footnotetext{
${ }^{44}$ For Project-related loans, if the applicable project requires "an Independent Review ... under Principle 7, the EPFI will require the appointment of an Independent Environmental and Social Consultant, or require that the borrower retain qualified and experienced external experts to verify its monitoring information which would be shared with the EPFI." See id. at Principle 9.

${ }^{45}$ EP II, supra note 27 , at Principle 10.

${ }^{46}$ Draft EP III, supra note 25 , at Principle 10.

${ }^{47}$ Paul Watchman, Banks, Business, and Human Rights, BUTTERWORTHS J. OF INT'L. BANKING AND FINANCIAL L., February 2006, 46 at 46, available at: http://www.banktrack.org (last accessed: 1 December 2012).

${ }^{48}$ ColleVECCHIO DeCLARATION ON FinANCIAL InSTITUTIONS (2003), available at: http://www.banktrack.org (last accessed: 1 December 2012)
} 
them a "helpful springboard from which financial institutions can examine and confront their role in destructive projects." ${ }^{49}$

Over the past decade, these hopes have faded. BankTrack, a civil society network that includes many of the NGOs that authored the Collevecchio Principles and that has monitored the Equator Principles' development, has expressed frustration with "how little the Principles have achieved; their limited effect on the protection of the planet's ecosystems, and on the lives of communities that are supposed to be the prime beneficiaries of the Principles." ${ }^{50}$ A strategic review launched by the Equator Principles Association found that representatives of some lenders have also become "frustrate[d] about inconsistent EP implementation among EPFIs." ${ }^{51}$ These representatives worry that the Equator Principles are "diminishing in brand value" because of these inconsistencies. ${ }^{52}$

\section{Do Lenders Make Effective Regulators?}

Can these problems be solved by working to improve the Equator Principles, or is the premise on which the Equator Principles are based - that lenders can act as effective regulators in the project finance sector - fundamentally flawed? Are there other regulators that are better placed to accomplish this task? Before responding to these questions, it is necessary to define some basic concepts, beginning with regulation.

Regulation is the exercise of control by one actor (the regulator) over other actors through (1) the setting of standards, (2) the monitoring of actors' conduct, both to assess compliance and to determine whether changes to existing standards are necessary, and (3) enforcement of these standards where compliance is inadequate. ${ }^{53}$ Unlike more direct forms of control, such as state ownership of a company or industry, regulation can be tailored to extend control only so far as necessary to achieve the regulator's objectives.

49 NGO Collective Analysis of the Equator Principles, GLOBALPOLICY.ORG (June 2003), available at: http://www.globalpolicy.org/component/content/article/213/45635.html (last accessed: 1 December 2012).

\footnotetext{
50 BankTrack, Bold Steps Forward: Towards Equator Principles that Deliver to People and Planet 2 (14 January 2010), available at: http://www.banktrack.org (last accessed: 1 December 2012).

51 Suellen lazarus \& Alan Feldbaum, Equator Principles Strategic Review final Report iii (17 February 2011), available at: http://www.equator-principles.com (last accessed: 1 December 2012).

52 Id.

${ }^{53}$ HOOD, ROTHSTEIN \& BALDWIN, supra note 7, at 24-28; Scott, supra note 7, at 67-68.
} 
While in the standard model of the regulatory relationship, a public authority regulates the actions of private actors, a number of other forms of regulatory relationship are possible. Internal government watchdogs, for instance, regulate other governmental organizations, ${ }^{54}$ and private actors may regulate the actions of other private actors. ${ }^{55}$

Regulatory relationships are complicated further by the fact that no regulatory relationship exists in a vacuum. Regulation exists within a regime, defined by Krasner as a set of "principles, norms, rules, and decision-making procedures around which actor expectations converge in a given issue-area." ${ }^{56}$ These norms may be shaped by regulators, the subjects of regulation, NGOs, and IGOs. ${ }^{57}$ Because these norms and principles shape the content of regulation in an issue area, it is necessary, when examining a regulatory framework, to keep in mind the regime it exists within. ${ }^{58}$

The Equator Principles are best viewed as existing within a broader regime aimed at mitigating environmental and social risks produced by businesses. ${ }^{59}$ Key actors within this regime include lenders, borrowers, NGOs, and governments. The Equator Principles give

\footnotetext{
${ }^{54}$ See generally Christopher HoOd et AL, Regulation InSIDE GOVERNMENT: WASTE-WATChers, QUALITY POLICE AND SLEAZE BUSTERS (1999).

55 See generally Tony Porter \& Karsten Ronit, Self-regulation as policy process: The multiple and criss-crossing stages of private rule-making, 39 POLICY SCIENCES 41 (2006).

${ }^{56}$ Stephen Krasner, Structural causes and regime consequences: regimes as international variables, 36 INT'L. ORG. 185, 185 (1982).

57 See e.g., Michael Levine \& Jennifer Forrence, Regulatory Capture, Public Interest, and the Public Agenda: Toward a Synthesis, 6 J.L. ECON. \& ORG. 167 (1990); Laurence Helfer, Regime Shift: The TRIPS Agreement and New Dynamics of International Lawmaking, 29 YALE J. INT'L. L. 1 (2004).

${ }^{58}$ HOOD, ROTHSTEIN \& BALDWIN, supra note 7, at 28.
}

\footnotetext{
59 See Tseming Yang \& Robert Percival, The Emergence of Global Environmental Law, 36 EcoLogY L.Q. 615, 616, 633 (describing the rise of a system of global environmental law, of which they claim the Equator Principles is a part; though they refer to this "set of legal principles developed by national, international, and transnational regulatory systems to protect the environment and manage natural resources" as a "body of law" rather than a regime, their emphases on converging expectations and approaches and the role of principles and norms that are not strictly binding, such as the Equator Principles, indicates that this system of principles can likely also be characterized as a regime).
} 
rise to two key regulatory relationships within this regime: (1) a relationship whereby lenders regulate the conduct of borrowers by means of loan agreements modeled on the Equator Principles, ${ }^{60}$ and (2) a relationship whereby lenders regulate each other's conduct through the creation of best practice standards that banks endeavor to incorporate into loan agreements. ${ }^{61}$ This article focuses on the first of these relationships, in part because assessing lenders' ability to ensure that other lenders adhere to the Equator Principles is a worthwhile endeavor only if the Equator Principles themselves provide an effective means of regulating borrowers' conduct. $^{62}$

Evaluating the effectiveness of any regulatory regime requires the assessment of incomplete, often qualitative evidence. Such evidence does not lend itself to the reaching of conclusive answers, and I do not presume to reach such conclusions here. My main objective, rather, is to help frame the debate in two ways. First, instead of engaging in an overall assessment of the Equator Principles' effectiveness, I look separately at lenders' ability to carry out three tasks central to regulation - standard setting, monitoring, and enforcement - in their regulatory relationships with lenders. Second, I consider whether other actors working within the same regime as the Equator Principles, such as governments or IGOs, are better placed to carry out these tasks.

\footnotetext{
${ }^{60}$ The use of contracts as a regulatory tool has been well-documented in existing literature. See e.g., Arthur Miller, Administration by Contract: A New Concern for the Administrative Lawyer, 36 N.Y.U. L. REV. 957 (1961); Michael Vandenburgh, The Private Life of Public Law, 105 Colum. L. ReV. 2029 (2005).

${ }^{61}$ See Ronen Shamir, Corporate Social Responsibility: Towards a New Market-Embedded Morality?, 9 THEOR'L INQ. L. 371, 385 (2008) (which describes the Equator Principles in the same terms).

${ }^{62}$ Evaluating the effectiveness of the second of these relationships also poses considerable challenges that require deeper examination than would be possible here. For example, how likely is it that Chinese and Russian banks, which account for a growing portion of the project finance sector, will be convinced to adopt the Equator Principles? By what means can the governance of the Equator Principles Association, along with the standards that apply to lenders' disclose of their implementation of the Equator Principles, be modified so as discourage lenders from free riding, that is, taking advantage of the reputational benefits of being associated with the Equator Principles without incurring the short term costs of compliance. For summaries of various stakeholders' views of these challenges, see Conley \& Williams, supra note 16, at 25-26; Lazarus \& Feldman, supra note 51, at 7, 9.
} 


\section{Standard Setting}

It is the act of setting standards that gives rise to a regulatory relationship, and it is for this reason that I consider it first here. ${ }^{63}$ Rather than assessing the substantive effectiveness of the Equator Principles, an analysis that has already been carried out in countless NGO reports, ${ }^{64}$ and which would likely lose its currency as the Equator Principles are revised, in this section I look more broadly at whether lenders possess characteristics likely to make them effective standard setters, and whether other actors could be better placed to set effective standards.

Generally, ${ }^{65}$ a regulator is seen as likely to set effective standards if it (1) is independent, ${ }^{66}$ (2) possesses relevant expertise, ${ }^{67}$ (3) follows procedures that are seen as fair, ${ }^{68}$ and (4) sets rules that reasonably relate to its policy objectives. ${ }^{69}$

${ }^{63}$ But see HOOD, ROTHSTEIN \& BALDWIN, supra note 7, at 24-28 (which begins by examining regulators' roles as monitors, on the basis that a regulator can only determine whether regulation is necessary by observing activity within a regime).

64 See generally Focus: The Equator Principles, BANKTRACK, available at: http://www.banktrack.org/show/pages/equator_principles (last accessed: 1 December 2012).

${ }^{65}$ I work from the assumption that regulation is an effective and legitimate means of achieving policy goals. I acknowledge, however, that this assumption is far from uncontroversial. See e.g., Gerald Frug, The Ideology of Bureaucracy in American Law, 97 HARV. L. REV 1276 (1983) (arguing for the replacement of impersonal regulatory bureaucracies, in the form of administrative agencies and corporations, with more participatory, communityoriented forms of governance); Ian Macneil, Bureaucracy, Liberalism and Community - American Style, 79 Nw. U. L. REV. 900, 901 (1984-85) (also citing "fundamental problems with a fully bureaucratized world").

${ }^{66}$ See e.g., IOSCO, Objectives and Principles of SeCURITIES Regulation, section 6.3 (2003), available at: http://www.iosco.org (last accessed: 1 December 2012) ("The regulator should be operationally independent from external political or commercial interference"); GIANDOMENICO MAJONE, REGULATING EUROPE (1996) 299-300 ("the root problem of regulatory legitimacy in Europe today is not an excess of independence but, on the contrary, the constant threat of politically motivated interference. With greater independence would go greater accountability"); Rachel Barkow, Insulating Agencies: Avoiding Capture through Institutional Design, 89 TEX. L. REV. 15, 17 (2010) ("policy makers seek to create independent agencies ... [in the hope that they] will better resist short-term partisan pressures and instead place more emphasis on empirical facts that will serve the public interest over the long term"); Cass Sunstein, Constitutionalism After the New Deal, 101 HARV. L. REV. 421, 500 (1987) (referring to "the New Deal conception of administration sought to insulate public officials in order to protect governmental processes against the distortions produced by factionalism").

${ }^{67}$ The presumption that technical expertise lends itself to superior decision-making dates back at least to the New Deal era. See e.g., JAMES LANDIS, THE AdMINISTRATIVE PRocess 23-24 (1938) ("with the rise of regulation, the need for expertness became dominant: for the art of regulating an industry requires knowledge of the details of its operation, the ability to shift requirements as the conditions of industry may dictate, the pursuit of economic measures upon the appearance of an emergency, and the power through enforcement to realize conclusions as 
The first factor, on its face, tends to weigh against lenders. Lenders are not independent, as their decision-making processes are driven in large part by their interest in producing a profit and increasing their share of the project finance sector at the expense of their competitors. But this lack of independence does not necessarily prevent lenders from setting effective standards. First, while financial institutions continue to view their interests as defined largely by short-term, firm-level considerations, there is a growing recognition that financial institutions' interests are more accurately defined primarily with reference to long-term, more systemic considerations, including global sustainable development. ${ }^{70}$ Second, bank executives view themselves and their employers not only as

to policy"); Sunstein, id. at 442 (referring to "the New Deal belief in the importance of technical expertise and immersion in the facts"). This view remains relevant today: see e.g., Ethyl Corp. v. EPA, 541 F.2d 1, 36 (D.C. Cir. 1976) ("the court must give due deference to the agency's ability to rely on its own developed expertise"); IOSCO, ObJectives ANd PRINCIPLES OF SeCURITIES Regulation, id. at section 6.4 (noting that an effective securities regulator "requires adequate funding ... [to] retain[] experienced staff").

${ }^{68}$ See e.g., IOSCO, OBJECTIVES AND PRINCIPLES OF SECURITIES REGULATION, id. at section 6.5 ("In exercising its powers and
discharging its functions, the regulator should adopt processes which are ... fair and equitable"); OECD, Engaging
Citizens in Policy-making: Information, Consultation and Public Participation (OECD Public Management Policy
Brief, No.10, July 2001) ("Strengthening relations with citizens ... allows government to tap new sources of policy-
relevant ideas, information and resources when making decisions"); Richard Stewart, U.S. Administrative Law: A
Model for Global Administrative Law?, 68 L. \& CONTEMP. PROBS. 63, 75 (2005, noting that procedural fairness in
rulemaking serves the "broader goal of promoting responsiveness and securing accountability to social interests
and values" [emphasis in original]); ALLEN LIND \& TOM TYLER, THE SOCIAL PSYCHOLOGY OF PROCEDUAL JUSTICE (1988) at
187 ("fair procedures lead to greater compliance with the rules and decisions with which they are associated").

${ }^{69}$ Though regulators, as noted above, are ideally expert in their field, courts, in reviewing the decisions of regulators established by legislatures, have routinely held that non-experts (i.e., courts) are capable of assessing whether regulatory standards reasonably relate to the policy goals defined in the regulator's enabling statute. See e.g., Chevron U.S.A. v. Natural Resources Defense Council, 467 U.S. 837, 843 (1984); Associated Provincial Picture Houses v. Wednesbury Corporation [1947] EWCA Civ 1, [1948] 1 K.B. 223; Jan Oster, Judicial Review in German and US Administrative Systems, 9 GERM. L.J. 1267, 1271 (2008), available at: http://www.germanlawjournal.com/pdfs/Vol09No10/PDF_Vol_09_No_10_1267-1296_Articles_Oster.pdf (last accessed: 1 December 2012, stating that judicial review in Germany, absent an explicit statement by the legislature on the issue of deference, is based on a similar consideration of whether the regulator's rulemaking is based on "irrelevant elements"). In assessing the reasonableness of the standards set in the Equator Principles, I look to standards set by other regulators within the same regime.

\footnotetext{
${ }^{70}$ See e.g., David Barton, Capitalism for the Long Term, 89(3) HARV. BuS. ReV. 84 (2011); James Hawley, Keith Johnson \& Edward Waitzer, Reclaiming Fiduciary Duty Balance, 2 RotMAN INT'L J. OF PENSION MGMT. 4 (2011); Andrew Haldane \& Richard Davies, The Short Long (Paper presented to the 29th Société Universitaire Européene de Recherches Finanacières Colloquium, Brussels, May 2011), available at: http://www.bankofengland.co.uk (last accessed: 1 December 2012).
} 
rational interest-maximizers, but as law-abiding, socially responsible (corporate) citizens. ${ }^{71}$ They are led to protect this self-image by adopting meaningful environmental and social standards, even if the adoption of these standards has no direct effect on shareholder value. $^{72}$ They understand that adopting meaningful private standards protects their reputations from attack by NGOs. ${ }^{73}$ Third, by setting meaningful standards and encouraging their competitors to do the same, lenders protect both their short- and longterm interests by ensuring that they are not undercut by competitors that are less likely to be targeted by NGOs. ${ }^{74}$

Furthermore, lenders fare somewhat better when one looks at the second criterion, expertise. Large commercial banks possess technical knowledge of the different kinds of projects built as a result of project finance through their due diligence. In negotiating and drafting loan agreements, they have acquired an understanding of the legal frameworks within which project finance operates. Through their work in developed countries, they have acquired an understanding of the regulatory frameworks for the management of environmental and social risk imposed by developed country governments. This expertise would seem to place banks in a stronger position than governments in LDCs or a new IGO, either of which would likely need to acquire new expertise to set effective standards. ${ }^{75}$

\footnotetext{
71 IAN Ayres \& John Braithwaite, Responsive Regulation: Transcending the Deregulation Debate 22 (1992); Margaret Blair \& Lynn Stout, Trust, Trustworthiness, and the Behavioral Foundation of Corporate Law, 149 U. PA. L. REV. 1735 , 1789-99 (2001, emphasizing the role of corporate law in framing corporate fiduciaries' view of their responsibility to act responsibly and in good faith, with adequate regard for the interests of others); Conley \& Williams, supra note 16, at 20-21 (noting that project finance professionals they surveyed cited lenders' motivation to "be a good citizen," along with sustained advocacy by "internal champions" working in lenders' upper echelons, as factors that contributed to widespread adoption of the Equator Principles). For a more incentives-based view of the value of a corporation's reputation as a good citizen, see Vandenbergh, supra note 1 , at 946-47.
}

72 See Andreas Hoepner \& John Wilson, Social, Environmental, Ethical and Trust (SEET) Issues in Banking: An Overview, in ReSEARCH HANDBOOK ON INTERNATIONAL BANKING AND GovernANCE 427, 447-48 (James R. Barth, Chen Lin \& Clas Wihlborg eds., 2012) (which reviews studies showing no obvious link between the adoption of environmental and social standards by banks and "financial performance" or "stock performance").

${ }^{73}$ See supra notes 20-22 and accompanying text.

\footnotetext{
74 Franck Amalric, The Equator Principles: a step towards sustainability?, at 5-6 (Working Paper Series, No. 1/5, Center for Corporate Responsibility and Sustainability, University of Zurich, 2005); O'Sullivan \& O'Dwyer, supra note 20, at 565. See also Vandenberg, supra note 1, at 947, 950 (describing how major firms in the retail sector have used similar tactics to protect themselves from smaller competitors).
}

${ }^{75}$ Antonio Vives, Corporate Social Responsibility: The Role of Law and Markets and the Case of Developing Countries, 83 CHI.-KENT L. REV. 199, 222 (2008); Kenneth Abbott \& Duncan Snidal, Strengthening International Regulation Through Transnational New Governance: Overcoming the Orchestration Deficit, 42 VAND. J. TRANSNAT'L 
That being said, lenders do not have a monopoly on expertise. For instance, governments and NGOs are likely better placed than lenders to understand the implications projects have for affected communities. Lenders are, however, capable of acquiring this expertise by following fair procedures before setting standards, as these procedures require the regulator to receive and consider submissions from these organizations and other interested parties.

The U.S. Administrative Procedure Act (USAPA) $^{76}$ and the Consultation Policy and Procedures of the International Organization of Securities Commissions (IOSCO Consultation Policy) ${ }^{77}$ provide models for the promulgation of fair standards. Both the USAPA and, generally, ${ }^{78}$ the IOSCO Consultation Policy require that the following procedures be followed before new standards are promulgated: (1) public notice must be given of the proposed rulemaking, (2) interested parties must be given a reasonable period of time (three months in the case of the IOSCO Consultation Policy, and generally 60 days in the case of the USAPA) ${ }^{79}$ to submit written comments on the proposed rulemaking, which are generally posted publicly by the regulator, and (3) the regulator must take these comments into account and address them a final release that explains the reasons for adopting the new rules. ${ }^{80}$

L. 501, 526 (2009) (noting that "firms' business expertise and management capacity," if brought to bear in the standard setting process, will result in more effective standards).

${ }^{76}$ Administrative Procedure Act, 5 U.S.C. section 553 (2011).

77 IOSCO, Consultation Policy and Procedure (April 2005), available at: http://www.iosco.org (last accessed: 1 December 2012).

${ }^{78}$ The IOSCO Consultation Policy does not formally require IOSCO to undertake a consultation process analogous to that set out in the USAPA before promulgating new standards. It takes a "flexible" approach, determining whether consultation is necessary based on the weighing of a number of enumerated factors. That being said, the policy does state that "projects that contemplate the issuance of international standards and principles for the securities sector will generally include the conduct of a public consultation as part of the project." Id. at 3 .

${ }^{79}$ Exec. Order No. 12,866, 3 C.F.R. 638 (1993), section 6(a)(1).

${ }^{80}$ IOSCO, Consultation Policy and Procedure, supra note 77, at 4; Administrative Procedure Act, 5 U.S.C. section $553(2011)$. 
The processes followed by the Equator Principles Secretariat when contemplating revisions to the Equator Principles follow this basic framework: draft revisions are posted publicly and interested parties are given an opportunity to comment on the draft, after which final revisions are promulgated. But this process falls short of the models described above in four respects. First, the Equator Principles include no rulemaking policy formalizing the process set out above. Instead, the Secretariat has created ad hoc consultation processes each time changes to the Equator Principles are contemplated. Second, while the time generally made available for the submission of comments (60 days) is the same as that generally made available under the USAPA, it falls short of the standard set by the IOSCO Consultation Policy. Lengthening the comment period to meet the IOSCO standard could help NGOs formulate more detailed comments - BankTrack, for example, has complained that the Secretariat's "rushed" rulemaking processes have made it more difficult to provide complete feedback. ${ }^{81}$ Third, in the case of the 2006 revision process, comments submitted were not posted on the Equator Principles website. ${ }^{82}$ As part of the 2012-13 process, however, the Secretariat has committed to post a summary of comments received. ${ }^{83}$ Fourth, in the case of the 2006 revision process, the Secretariat did not explain how the comments it received were addressed in the final revisions. ${ }^{84}$ The Secretariat has, however, committed to offer such explanations in the $2012-13$ process. ${ }^{85}$

${ }^{81}$ BankTrack et. al., Equator Principles II: NGO comments on the proposed revision of the Equator Principles, BANKTRACK (26 April 2006), available at: http://www.banktrack.org (last accessed: 1 December 2012).

82 Press Release, Equator Principles, EPFls Review of Equator Principles (8 June 2006), available at: http://www.equator-principles.com (last accessed: 1 December 2012); Press Release, Equator Principles, Financial Institutions Announce Revision of the Equator Principles Underscoring the Global Application of Environmental and Social Risk Management (6 July 2006), available at: http://www.equator-principles.com (last accessed: 1 December 2012).

${ }^{83}$ About Equator Principles Update and Timeline, EQUATOR PRINCIPLES, http://www.equator-principles.com (last accessed: 1 December 2012). Some commenters have posted their full comments on their websites. See e.g., BankTrack, Tiny Steps Forward on the Outside Job: Comments on the Equator Principles III Official First Draft (10 October 2012), available at: http://www.banktrack.org (last accessed: 1 December 2012).

${ }^{84}$ Press Release, Equator Principles, EPFls Review of Equator Principles (8 June 2006), supra note 82; Press Release, Equator Principles, Financial Institutions Announce Revision of the Equator Principles Underscoring the Global Application of Environmental and Social Risk Management (6 July 2006), supra note 82.

${ }^{85}$ About Equator Principles Update and Timeline, supra note 83. 
In summary, the process the Equator Principles Association has generally followed (though not formalized) allows it access to relevant information when it considers revisions to the Equator Principles, and the improved procedures adopted for the 2012-13 revision process show that lenders are capable of bringing their rulemaking processes more closely into line with the processes broadly followed by governmental and intergovernmental regulators.

The standards lenders have produced using the procedures listed above are also similar to those promulgated by other regulators working within the same regime as the Equator Principles. First, the stakeholder engagement and grievance processes described in Principles 5-6, which involves disclosure of relevant information to stakeholders, dialogue with stakeholders, and access to grievance mechanisms for stakeholders harmed by a project, generally aligns with the rights to (1) access environmental information held by public authorities, (2) participate in environmental decision-making, and (3) access to justice where there is a violation of environmental law, which are recognized throughout international environmental law. ${ }^{86}$ The Equator Principles' emphasis on procedural requirements (e.g., the preparation of an Assessment and ESMP) rather than substantive outcomes, and reliance on regulated entities to research and propose means of addressing the environmental and social risks posed by their projects, also places the Equator

\footnotetext{
${ }^{86}$ These rights have been recognized in the Rio Declaration of 1992, the Aarhus Convention of 1998, and by a 2000 resolution of the Organization of American States. Report of the United Nations Conference on Environment and Development, UN Doc A/CONF/151/26 (Vol. I), Annex I (1992); Convention on Access to Information, Public Participation in Decision-Making and Access to Justice in Environmental Matters, 25 June 1998, reprinted in I.L.M., vol. 38, 1999, 517; Organization of American States, Inter-American Strategy for the Promotion of Public Participation in Decision Making for Sustainable Development CIDI/RES. 98 (V-o/00), OEA/Ser.W/II.5, CIDI/doc.25/00 (20 April 2000).
} 
Principles broadly within the category of reflexive law, ${ }^{87}$ a category in which many authors argue global environmental law tends to belong. ${ }^{88}$

Second, the Equator Principles answer NGOs' call to incorporate best practices developed by other regulators. ${ }^{89}$ For instance, they incorporate the IFC Performance Standards and Environmental, Health and Safety Standards, in addition to local law. ${ }^{90}$ Draft EP III will incorporate newly-developed standards, such as IFC standards for the mitigation of projects' effects on climate change, along with the 2007 UN Declaration on the Rights of Indigenous Peoples' requirement that the "free, prior and informed consent" of Aboriginals be obtained before construction of a project begins. ${ }^{91}$ It also acknowledges the "Protect, Respect and Remedy" Framework for business and human rights adopted by the UN Human Rights Council in 2011. ${ }^{92}$

\footnotetext{
${ }^{87}$ Reflexive law rejects legal formalism's contention that law and regulation have an innate logic. It also rejects the contention, inherent in welfare state-style regulation, that public authorities have the capacity to set detailed rules that serve the interests of society as a whole. It holds that society is in fact fragmented into different, increasingly specialized social systems led by distinct fields of experts. Law is merely another form of social system, and legal experts are often not capable of accurately predicting how the rules they promulgate will affect behavior within the external social systems they aim to regulate. The proper role of regulation, it holds, is to design procedures that allow for dialogue within each of these social systems, with the aim of developing tentative and experimental regulatory frameworks that reflect the culture and policy goals of the social systems to which these frameworks would apply. See Gunther Teubner, Substantive and Reflexive Elements in Modern Law, 17 LAW \& Soc'Y Rev. 239 (1983); Niklas Luhmann, Operational Closure and Structural Coupling: The Differentiation of the Legal System, 13 CARDozo L. REV. 1419 (1992); Gunther Teubner, Autopoiesis in Law and Society: A Rejoinder to Blankenburg, 18 LAW \& Soc'Y REV. 201 (1984); Peer Zumbansen, Law after the Welfare State: Formalism, Functionalism and the Ironic Turn of Reflexive Law, 56 AM. J. CoMP. L. 769, 789-95 (2008). See also Dennis D. Hirsch, Green Business and the Importance of Reflexive Law: What Michael Porter Didn't Say, 62 ADMIN. L. REV. 1063, 1107-1108 (2010) (citing the U.S. Clean Air Act New Source Review program, which had the effect of increasing emissions from industry, as an example of how legislators' and legal experts' lack of understanding of the systems they seek to regulate can lead to undesirable outcomes).
}

${ }^{88}$ Hirsch, id.; Sanford E. Gaines, Reflexive Law as a Legal Research Paradigm for Sustainable Development, 10 BUFF. ENVTL. L.J. 1 (2002-2003).

${ }^{89}$ See ColleVecchio DeClaration on FinanCial Institutions, supra note 48 , at section 2(b).

${ }^{90}$ Draft EP III, supra note 25, at Principle 3; EP II, supra note 27, at Principle 3.

${ }^{91}$ Declaration on the Rights of Indigenous Peoples, UN Doc. A/C.3/61/L.18/Rev.1 (2007); Draft EP III, id. at Principle 5.

${ }^{92}$ Human rights and transnational corporations and other business enterprises, Human Rights Council Res. 17/4 of 6 July 2011; Draft EP III, id. at Preamble. 
These aspects of the Equator Principles have not gone unnoticed. Yang \& Percival place the Equator Principles within a system of "global environmental law," where "the deliberate copying and adaptation of significant portions of statutes or particular doctrines of law," the convergence of norms "as a response to similar external pressures," and "multicountry efforts of legal cooperation and standardization that result in similar legal approaches" have become commonplace. ${ }^{93}$

Though the above review is far from exhaustive, ${ }^{94}$ it does indicate that the Equator Principles have much in common with standards set by other environmental regulators. This, together with the relatively fair procedures used by lenders when revising the Equator Principles and lenders' relative expertise in the project finance sector, means that lenders are relatively well-placed to set standards that, if implemented, will cause borrowers to act in a way that furthers the stated goals of the Equator Principles. While lenders are not independent, the reputational and other risks that would stem from a decision to deliberately set ineffective standards likely cause lenders to take the task of standard setting seriously.

\section{Monitoring}

That being said, the standards set by a regulator are unlikely to be effective unless there is some mechanism by which the regulator can monitor compliance with these standards (and thus determine whether enforcement action is necessary). Hood, Rothstein and Baldwin identify three types of monitoring: (1) active monitoring, where the regulator directly investigates actors' conduct; (2) passive monitoring, where the regulator relies on other actors to report incidents of non-compliance; and (3) interactive monitoring, where the regulator imposes periodic reporting requirements on regulated actors and reviews these reports to determine compliance..$^{95}$ While active monitoring mechanisms are more likely to give the regulator access to unvarnished information about actors' activities, passive and interactive mechanisms are more cost effective, shifting the costs of investigation from regulators to third parties.

\footnotetext{
${ }^{93}$ Yang \& Percival, supra note 59, at 626-27, 633.
}

\footnotetext{
${ }^{94}$ See David M. Ong, From 'International' to 'Transnational' Environmental Law? A Legal Assessment of the Contribution of the 'Equator Principles' to International Environmental Law, 79 NORDIC J. INT'L L. 35, 51-72 (2010) (which provides a more complete comparison of the Equator Principles with other environmental norms, but which also concludes that the Equator Principles accord, albeit not perfectly, with these norms).
}

\footnotetext{
${ }^{95}$ HOOD, ROTHSTEIN \& BALDWIN, supra note 7, at 24-25.
} 
Draft EP III and its predecessors rely almost entirely on interactive and passive monitoring mechanisms. It is the borrower that prepares the Assessment, ESMP, and ESMS, and that implements any necessary stakeholder engagement or grievance mechanism. The lender's initial categorization of a project's risk, and of whether an AP is necessary, is based on a review of documents prepared by the borrower. In addition, lenders (along with the public at large) often receive information from NGOs and other interested persons alleging that a project is not in compliance with the Equator Principles; these actors collect this information by conducting onsite investigations of a project and reviewing the borrower's disclosure documents. ${ }^{96}$ As NGOs and other actors come forward with this information unprompted by lenders, their work can best be classified as a form of passive monitoring of borrowers' compliance.

The only instances where the Equator Principles may provide for active monitoring are where, under Principle 4 of Draft EP III (but not EP II), the lender formulates an AP in conjunction with the lender, and where, under Principle 7, an independent reviewer retained to review a borrower's disclosure documents requests permission to carry out an onsite inspection of a project (a possibility that neither EP II nor Draft EP III explicitly contemplate). ${ }^{97}$

Several authors have indicated that interactive monitoring through the due diligence process, even without additional scrutiny from NGOs, is a highly effective means of monitoring compliance with environmental and other standards. ${ }^{98}$ Lenders have an interest in carefully reviewing documentation supplied by borrowers for any fact or omission that reduces the odds that the project will be completed on schedule, including those stemming from environmental and social risk. ${ }^{99}$ Likewise, in addition to any

\footnotetext{
${ }^{96}$ These investigations are not intended as a service to lenders. Their results are shared with the public at large and used as a means of pressuring lenders into using their leverage to bring project companies into compliance with the Equator Principles, as interpreted by the investigating NGO. This dynamic will be explored further in this subsection below, and in subsection C(III).

${ }^{97}$ Draft EP III, supra note 25, at Principles 4, 7; EP II, supra note 27, at Principles 4, 7.
}

${ }^{98}$ Vandenburgh, supra note 60, at 2054 ("Anecdotal accounts suggest, though, that a substantial amount of lender enforcement occurs both before and during the term of the loan"); Frederick Tung, Leverage in the Boardroom: The Unsung Role of Private Lenders in Corporate Governance, 57 UCLA L REV 115, 117 (2009) ("banks and other private lenders exercise influence over firm management that is both routine and significant"); Michael Gerrard, Trends in the Supply and Demand for Environmental Lawyers, 25 CoLUM. J. ENVTL. L. 1, 3 (2000) (“Banks, frightened by a tiny handful of lender liability cases, became the most diligent enforcers of environmental law").

${ }^{99}$ YESCOMBE, supra note 9, at sections 8.2, 8.6. 
perceived social responsibility to be truthful in their disclosure to lenders, ${ }^{100}$ borrowers and sponsors have an immediate interest in providing information to lenders that is not misleading as to the degree and nature of the risks posed by a project. Borrowers generally must represent and warrant that material supplied to the lender is true in all material respects. To supply the borrower with information that does not meet this standard may lead the lender to more closely scrutinize, and impose additional constraints on, the borrower's operations; the lender may also impose a higher interest rate or demand immediate repayment of the loan. ${ }^{101}$

The controversy surrounding the Theun-Hinboun Power Expansion Project (THXP), a dam and diversion project located in central Laos and financed by several EPFIs, sheds some light on how accurate this hypothesis is in respect of the Equator Principles. The TXHP is being undertaken by the Theun-Hinboun Power Company (THPC), whose lead sponsor is EDL-Generation Public Company, a Lao company whose controlling shareholder is Electricité de Laos, a state-owned corporation. ${ }^{102}$ In late 2008, THPC secured a syndicated loan of US\$187.5 million from Exim Bank of Thailand, the French-based BNP Paribas S.A., Australia and New Zealand Banking Group (ANZ Bank), and Belgium-based KBC Groep NV. ${ }^{103}$ The latter three banks are all EPFIs. ${ }^{104}$

THXP builds on the existing Theun-Hinboun Hydro Electric Power Station, which was inaugurated in 1998 and attracted considerable criticism for NGOs for, in their view, mismanaging or failing to deliver on promised measures to relocate and compensate persons displaced by the project. ${ }^{105}$ THXP will expand the existing plant's generating

${ }^{100}$ See supra notes 71-72 and accompanying text.

101 Tung, supra note 98, at 150-52. The range and likelihood of enforcement action in respect of the Equator Principles will be addressed in subsection C(III), below.

${ }^{102}$ About the Company: Shareholders, THPC, available at: http://www.thpclaos.com (last accessed: 1 December 2012).

${ }^{103}$ Theun Hinboun: Hydro against the current, PROJECT FIN. \& INFRASTRUCTURE FIN., April 2009, at 38.

\footnotetext{
104 Equator Principles, Members \& Reporting, EQUATOR PRINCIPLES (15 May 2012), available at: http://www.equator-
} principles.com (last accessed: 1 December 2012).

105 Keith Barney, Power, Progress and Impoverishment: Plantations, Hydropower, Ecological Change and Community Transformation in Hinboun District, Lao PDR: A Field Report 13-45 (York Centre for Asian Research Papers, No. 1, 2007); AsSOCIATION FOR INTERNATIONAL WATER STUDIES (FIVAS), RUINED RIVERS, DAMAGED LIVES: THE IMPACTS OF the Theun-Hinboun Hydropower Project on DOWNStream COMMUNities IN LAO PDR 46-50 (2007), available at: http://www.internationalrivers.org (last accessed: 1 December 2012). For example, efforts to set aside new land 
capacity by building a $65 \mathrm{~m}$ (213 ft) high dam on the Nam Gnouang river, about $27 \mathrm{~km} \mathrm{(17}$ miles) upstream of the existing plant. This dam will create a reservoir that will flood an area of 105 square $\mathrm{km}$ (41 square miles) during the wet season, falling to 15 square $\mathrm{km} \mathrm{(6}$ square miles) during the dry season. The periodic release of water from the dam downstream into the Nam Hai and Nam Hinboun rivers will cause more frequent and severe flooding of these rivers. ${ }^{106}$

According to the Environmental Impact Assessment, ${ }^{107}$ Environmental Management and Monitoring Plan, ${ }^{108}$ and Resettlement Action Plan ${ }^{109}$ prepared by Norplan S.A. at the request of THPC (collectively, the "Norplan Reports"), the effects of the flooding will include increases in sediment in the rivers (due to erosion), harm to vegetation and wildlife, and the displacement of an estimated 4,186 people living in the reservoir area. Another 24,154 people living on the banks of the Nam Hai and Nam Hinboun will also be affected by increased flooding and the resulting destruction of crops and reduction of the fish population. The Norplan Reports estimate that a total of 55,627 people will be affected by THPX. ${ }^{110}$ The Norplan Reports conclude, however, that provided THPC implements a

for farmers to plant crops reportedly failed in a number of villages due to problems with the irrigation systems supplied by THPC and managed by village governments. THPC has reportedly stated that "[p]oor leadership and internal conflict [among village leaders] are the main reasons for the failure of programs that have been successful or at least more successful in other villages." See Barney, id. at 26, n.14. Furthermore, these measures were not promised until 2000, two years after the project was completed, and only after sustained pressure from

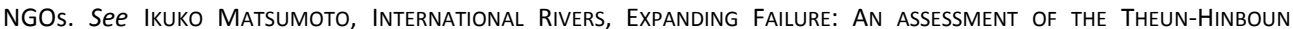
HYdRopoWer EXPANSION PROJECT's COMPLIANCE WITH EquATOR PRINCIPLES AND LAO LAW 7-8 (5 November 2009), available at: http://www.internationalrivers.org (last accessed: 1 December 2012).

${ }^{106}$ Norplan S.A., Theun Hinboun Expansion Project, Final EiA/EMMP, Section 1: EIA, section 6.2 .2 (30 April 2008), available at: http://www.thpclaos.com (last accessed: 1 December 2012) [hereinafter “Norplan EIA"].

${ }^{107}$ Id.

${ }^{108}$ Norplan S.A., Theun Hinboun Expansion Project, Final EIA/EMMP, Section 2: EnVIRonmental Management and MONITORING PLAN (30 April 2008), available at: http://www.thpclaos.com (last accessed: 1 December 2012) [hereinafter "Norplan EMMP"].

\footnotetext{
109 Norplan S.A., Theun hinboun Expansion Project, Final Report, Resettlement Action Plan, Part 1 - Overarching ISSUES (30 April 2008), available at: http://www.thpclaos.com (last accessed: 1 December 2012) [hereinafter "Norplan RAP"].

${ }^{110}$ Norplan S.A., Theun Hinboun Expansion Project, Final RAP EXeCutive Summary xiv (30 April 2008), available at: http://www.thpclaos.com (last accessed: 1 December 2012) [hereinafter "Norplan RAP Executive Summary"].
} 
series of mitigation and stakeholder engagement measures, the THPX can be built in accordance with Lao law, Laos's international commitments, and the policies of the Asian Development Bank and World Bank. ${ }^{111}$

Several research reports, most of which have been prepared by NGOs, have alleged that the Norplan Reports underestimated the risks posed by THPX. ${ }^{112}$ These include the risks that sediment produced by flooding, along with drops in oxygen as a result of the decomposition of organic material submerged by the reservoir, will harm plants and wildlife in and near the Nam Gnouang, Nam Hai and Nam Hinboun rivers. ${ }^{113}$ NGO reports have also alleged that the stakeholder engagement and risk mitigation processes the Norplan Reports recommend would not be sufficient to establish compliance with Lao law and the environmental and social standards set by the IFC, which are the applicable standards for assessing and determining how to mitigate environmental and social risk in non-High Income OECD Countries under the Equator Principles. ${ }^{114}$

It would not be possible in this article to adjudicate the opposing claims made in the longrunning and well-documented dispute between NGOs and THPC over the latter's compliance with the Equator Principles. ${ }^{115}$ My sole objective here is to determine whether the disclosure made by THPC to prospective lenders in the form of the Norplan Reports would be sufficient either to establish compliance with the Equator Principles or to establish whether further inquiries into compliance were necessary.

A cursory review of the Norplan Reports reveals several problems that would lead a reasonable lender to request further disclosure from THPC or undertake its own

\footnotetext{
${ }^{111}$ Norplan EIA, supra note 106, at section 6.4, Norplan RAP, supra note 108, at sections 2.1-2.4 (describing the policies with which the RAP is intended to comply); Norplan EMMP, supra note 108, at sections 9.1-9.3. The ADB is not involved in the financing of THPX but did finance the initial construction of the Theun Hinboun power plant. See Ted Bardacke, 'Battery of Asia' may run flat: Thailand's economic crisis is raising questions over the energy exporting hopes of neighbouring Laos, FIN. TIMES, 6 April 1998 at 3.

${ }^{112}$ See e.g., David J.H. Blake, Review of Draft Final EIA/EMMP for Theun-Hinboun Expansion Project, Lao PDR 2-8 (April 2008) (unpublished manuscript), available at: http://www.internationalrivers.org (last accessed: 1 December 2012); МАтSUMOTO, supra note 105, at 14.

${ }^{113}$ Blake, id. at 5-6.

${ }^{114}$ Matsumoto, supra note 105, at 11-25; EP II, supra note 27, at Principle 3.

${ }^{115}$ See infra notes 122, 124.
} 
investigation. First, the Norplan Reports are not based on Norplan S.A.'s own investigation of the project-affected areas. It is based entirely on reports by other agencies, ${ }^{116}$ including an environmental consultant originally retained by THPC to produce an Environmental Assessment but later dismissed for reasons that remain in dispute. ${ }^{117}$ Second, the Norplan Reports do not mention the Equator Principles or the IFC Performance Standards, instead basing their analysis solely on Lao law, treaties to which Laos is a party, and safeguards adopted by the World Bank and Asian Development Bank. ${ }^{118}$

As a result, the stakeholder engagement process outlined in the Resettlement Action Plan does not identify or explain the "free, prior and informed consultation" standard set by the IFC Performance Standards and the Equator Principles or how the engagement process it documents would meet these standards. ${ }^{119}$ In addition, while many of the ethnic minorities living in project-affected areas would likely be defined as "Indigenous Peoples" under the IFC Performance Standards, the Norplan Reports do not explain or identify how the elevated engagement standards that apply to Indigenous Peoples under these standards would be fulfilled. ${ }^{120}$

It would be reasonable to conclude that, before agreeing to finance THPX in 2008, BNP Paribas, KBC, and ANZ Bank were aware of these shortcomings, together with the concerns raised by NGOs and the well-documented problems with the mitigation measures implemented under the initial Theun-Hinboun Hydropower Project. It would be reasonable to conclude that they had sufficient information at their disposal to know that further

\footnotetext{
${ }^{116}$ Norplan EIA, supra note 106, at sections 1.2-1.3 (this text applies to both the EIA and the EMMP); Norplan RAP, supra note 109 , at section 1.2 .

117 While THPC maintains that the reports produced by RMR were not in a format that met Lao legal requirements, RMR's heavy criticism of the Norplan Reports' characterization of THXP's environmental and social risks indicates that RMR may have been dismissed because it refused to frame these risks in a way that was favourable to THPC. See Blake, supra note 112, at 1-2; Tom Fawthrop, A dam shame, THE GUARDIAN / COMMENT IS FREE, 24 September 2008, available at: http://www.guardian.co.uk/commentisfree/2008/sep/24/energy.norway (last accessed: 1 December 2012); Norplan EIA, supra note 106, at section 1.2; Norplan RAP, supra note 109, at section 1.2

${ }^{118}$ Norplan EIA, id. at sections 2.1-2.3; Norplan RAP, id. at sections 2.1-2.5.

119 See IFC, Performance Standards, Performance Standard and Guidance Note 7: Indigenous Peoples, paras. G3, G14-G31 (2006), available at: http://www.ifc.org (last accessed: 1 December 2012); EP II, supra note 27, at Principle 5.

${ }^{120}$ See IFC, id.
} 
questions would need to be asked of THPC to assess its compliance with the Equator Principles.

Yet these banks did not require that the Norplan Reports be revised to address the Equator Principles and IFC standards before agreeing to loan to THPC. They did, however, send a technical advisor to carry out onsite inspections of THPX in 2009. Both THPC and the technical adviser have asserted that THPX complies with these standards, ${ }^{121}$ though NGOs doubt these findings. ${ }^{122}$

THPC continues to disclose information to the public about the construction of THPX (scheduled to be completed in late 2012) and the effectiveness of its mitigation and compensation efforts. THPC has also produced detailed (though not always wholly responsive) $)^{123}$ replies to questions and concerns raised by NGOs. ${ }^{124}$

The debate over THPX indicates that the largely interactive and passive monitoring mechanisms lenders rely upon, even when supplemented by research by NGOs and interested individuals, may not supply a lender with all of the information necessary to assess compliance with the Equator Principles. They do, however, offer some indication as to when additional information is necessary to assess a borrower's compliance.

It may be prudent for the Equator Principles to explicitly authorize independent experts appointed under Principle 7 (to review a borrower's due diligence disclosure) or Principle 9 (to review a borrower's ongoing disclosure) to carry out onsite inspections and investigations of the project site and affected communities to seek out information that

121 THPC, THPC RESPONSE tO INTERNATIONAL RIVERS REPORT 1 (21 December 2009), available at: http://www.thpclaos.com (last accessed: 1 December 2012).

122 See generally Dodgy Deals: Theun-Hinboun dam expansion project, BANKTRACK, available at: http://www.banktrack.org (last accessed: 1 December 2012).

${ }^{123}$ For example, THPC has repeatedly refused to concede that the ethnic minorities who will be affected by the construction of the dam qualify as indigenous peoples. It claims that the term "indigenous peoples" is generally not used in Asia, even though the Norplan Reports classify these individuals as indigenous peoples, and ADB policy in place when THXP was launched supports the classification of certain classes of ethnic minorities as indigenous people. See id. at 4; THPC, THPC RESPONSE TO BANKTRACK, NETHERLANDS 1 (24 May 2010), available at: http://www.thpclaos.com (last accessed: 1 December 2012); ADB, POLICY ON INDIGENOus PeOPLE (April 1998), available at: http://www.adb.org (last accessed: 1 December 2012).

${ }^{124}$ See generally Documents: Project Implementation, THPC (May 2012), available at: http://www.thpclaos.com (last accessed: 1 December 2012, which includes three responses to reports by NGOs, the most recent of which was released in May 2012). 
may not be captured in the borrower's reports. These measures would also reduce the burden currently placed on NGOs, which at present act, as one NGO representative has put it, as "free consultants" for lenders, incurring significant investigative costs while lenders reap considerable pecuniary rewards from the projects they finance. ${ }^{125}$

\section{Enforcement}

Monitoring mechanisms exist largely to determine whether enforcement action is necessary. Enforcement includes any means by which a regulator seeks to cure noncompliance with a regulatory framework. As Ayres and Braithwaite note, it includes both the application of sanctions and less coercive means of curing non-compliance, such as persuasion and the provision of information on applicable standards. ${ }^{126}$ They argue that most regulated entities are motivated to comply with regulation out of a sense of social responsibility, and as such, appeals to social responsibility are generally the most effective means of achieving compliance. Excessive reliance on coercive means of enforcement, they add, risks alienating regulated entities and causing them to seek to evade regulation or hide material information form a regulator. ${ }^{127}$

They recommend that regulators adopt an "enforcement pyramid," with non-coercive enforcement mechanisms at the base (as these tactics should be both the first and most common response to non-compliance), and more coercive means lying higher up on the pyramid (as these tactics should be employed only where less coercive tactics fail). ${ }^{128}$ An enforcement pyramid for the Equator Principles could be ordered as follows (from base to peak):

(1) persuasion, whereby the lender advises the borrower on how to comply with the Equator Principles and appeals to the borrower's sense of social responsibility in encouraging it to do so;

(2) the issuance of a warning to the borrower, which appeals to the borrower's sense of rationality by highlighting the possible consequences of continued non-

\footnotetext{
${ }^{125}$ O'Sullivan \& O'Dwyer, supra note 20, at 573.

${ }^{126}$ AYRES \& BRAITHWAITE, supra note 71 , at $19-20$.

${ }^{127}$ Id. at 26 .

${ }^{128}$ Id. at 35-38. See also Scott, supra note 7, at 69-70; Tung, supra note 98, at 550-52 (which indicates that the tactics lenders use when enforcing loan agreements tend to follow this model).
} 
compliance (i.e., withdrawal from negotiations if a loan agreement has not been signed, and declaration of a default event where a loan agreement has been signed);

(3) negotiated changes to the (proposed) loan agreement that favour the lender (e.g., tighter constraints on the borrower's operations or a higher interest rate for the lender), or the negotiated withdrawal of financing by the lender;

(4) if the borrower refuses to negotiate and a loan agreement has been signed, the declaration of a default event and the launch of a civil complaint by the lender if the borrower fails to return the lender's financing.

Ayres and Braithwaite add a caveat to their enforcement pyramid model: its effectiveness depends on the existence of a credible deterrent - a belief on the part of regulated actors that, if they fail to comply with the regulator's less coercive means of enforcement, they will face more severe enforcement action. ${ }^{129}$

The Equator Principles may not provide this credible deterrent. Lenders are likely unwilling to bear the short-term costs of extricating themselves from a project, especially after they have already committed financing or tentatively agreed to play a lead role in a project (e.g., as loan arranger). By negotiating its withdrawal from a project, a lender cedes any prospect of a return on any funds it has already invested in due diligence. It also cedes a share of the profits that will likely accrue from the project, profits that will likely flow to a less scrupulous competitor. More severe enforcement action would be even more costly: the declaration of a default event and the seeking of a civil remedy in court, for instance, would mean drawn-out litigation, where the lender's success is far from guaranteed. Given financial institutions' general tendency to emphasize short-term over long-term interests, a tendency that has become more salient with the advent of the most recent financial crisis, ${ }^{130}$ these short-term costs are likely to overwhelm any longer-term, more systemic concerns that may favor meaningful enforcement.

Experience seems to support this view of lenders' interests. As of September 2012, no EPFI has declared a default event on the basis of a breach of the Equator Principles. There are only a handful of cases where an EPFI has withdrawn from a project in the face of apparent breaches of the Equator Principles. ${ }^{131}$

\footnotetext{
${ }^{129}$ AYRES \& BRAITHWAITE, id. at 36.

${ }^{130}$ See supra note 70.

${ }^{131}$ ING ended its involvement with the proposed Botnia paper mill to be built on the Uruguay River in 2006. This incident is addressed later in this subsection. See also ANZ and Gunns Limited's proposed Bell Bay Pulp Mill, ANZ (May 2008), available at: http://www.anz.com (last accessed: 1 December 2012); Press Release, The Wilderness
} 
One of these cases was the March 2006 withdrawal of ING Groep N.V. (ING) from its roles as financial adviser and loan arranger from the Botnia paper mill project in Uruguay. The Botnia project was launched in 2003, when Norway-based Metsä Fibre (then named OyMetsa Botnia S.A.) expressed its interest in sponsoring the construction of a paper mill on the Uruguay River, which divides Uruguay from its neighbor, Argentina. ${ }^{132}$ Botnia S.A., a newly incorporated subsidiary of Metsä Fibre, was to act as project company.

The project enjoyed the full support of the Uruguayan government, which believed that the paper mill, expected to cost US\$1.2 billion and produce more than one million tons of air dried pulp each year, would contribute significantly to the country's economic growth. ${ }^{133}$ By 2005 , several financial institutions, including ING and the IFC, had expressed interest in financing the project.

The project was less well-received, however, by the Argentinian government, and by local NGOs in both Uruguay and Argentina. They feared that the pulp mill would pollute the Uruguay River and emit noxious fumes; Argentina feared these effects would harm a thriving tourist industry on the Argentinian side of the Uruguay River. ${ }^{134}$

In September 2005, the Center for Human Rights and Environment (CEDHA), an NGO based in Argentina, filed a complaint with the IFC's Compliance Advisor/Ombudsman (CAO) alleging that Botnia S.A. had failed to comply with the IFC Safeguards (the predecessor to the IFC Performance Standards). ${ }^{135}$ In December 2005, it filed a complaint with ING alleging that the Environmental Impact Assessment (EIA) and stakeholder engagement process

Society, NGOs welcome ANZ decision not to finance Gunns proposed pulp mill (28 May 2008), available at: http://www.banktrack.org (last accessed: 1 December 2012, discussing ANZ Bank's 2008 decision not to provide a loan to finance the proposed Gunns pulp mill to be built in Tazmania).

${ }^{132}$ IFC/Multilateral Investment Guarantee Agency (MIGA), Compliance Advisor/Ombudsman (CAO), Complaint Regarding IFC's Proposed Investment in Celulosas de M'Bopicuá and Orion Projects, Uruguay, Preliminary Assessment Report 4 (November 2005), available at: http://www.cao-ombudsman.org (last accessed: 1 December 2012) [hereinafter "IFC/MIGA, CAO, Preliminary Assessment Report"].

${ }^{133} / d$.

${ }^{134}$ CEDHA, Complaint Regarding IFC's Proposed Investment in Celulosas de M'Bopicuá and Orion Projects, Uruguay 7, 9-12 (September 2005), available at: http://www.cao-ombudsman.org (last accessed: 1 December 2012) [hereinafter "CEDHA, CAO Complaint"].

${ }^{135}$ Id. 
prepared by Botnia S.A. had also failed to comply with the Equator Principles. ${ }^{136}$ The complaint to the CAO included over 39,000 signatures of support, including that of the Governor of the province of Entre Rios, Argentina. ${ }^{137}$ The complaints alleged that Botnia S.A. failed to consider the effects the Botnia project would have on Argentina. Its EIA, CEDHA noted, addressed possible environmental and social risks to Uruguay, but not Argentina. While Botnia engaged with stakeholders in Uruguay, it did not meet with stakeholders in Argentina. ${ }^{138}$

The CAO, in a preliminary assessment released in November 2005 and a formal audit of the IFC's due diligence released in February 2006, agreed that Botnia S.A.'s disclosure and consultation processes were insufficient to establish compliance with the IFC Safeguards. ${ }^{139}$ By this time, the IFC had already begun work on a Cumulative Impact Study (CIS) that was intended to address the shortcomings in the work prepared by Botnia S.A. ${ }^{140}$ Nonetheless, NGOs mounted further pressure on ING to end its involvement with the project. $^{141}$

136 Letter from Jorge Daniel Taillant, CEDHA, to ING Groep N.V. (December 2005), available at: http://casopasteras.cedha.net/wp-content/uploads/2011/09/complaint-letter-to-ing-eng.pdf (last accessed: 1 December 2012) [hereinafter "CEDHA, Equator Principles Complaint"]; see also Annie Dufey \& Diana Morales, Orion and CMB Pulp Plants in Uruguay, in GLOBAL ProjeCt FinANCE, HumAn RIGHTS AND SUSTAINABLE DeVelopment 416, 451-52 (Sheldon Leader \& David Ong, eds., 2011).

${ }^{137}$ CEDHA, CAO Complaint, supra note 134 , at 2.

${ }^{138}$ Id; CEDHA, Equator Principles Complaint, supra note 136, at 5.

139 IFC/MIGA, CAO, Preliminary Assessment Report, supra note 132, at 9-12; IFC/MIGA, CAO, CAO Audit of IFC's and MIGA's Due Diligence of Celulosas de M'Bopicua and Orion Paper Mills 25-26 (22 Februrary 2006), available at: http://www.cao-ombudsman.org (last accessed: 1 December 2012).

${ }^{140}$ IFC/MIGA, CAO, Complaint Regarding IFC's Proposed Investment in Celulosas de M'Bopicuá and Orion Projects, Uruguay, IFC's Response to Preliminary Assessment Report 1, 3-5 (January 2006), available at: http://www.caoombudsman.org (last accessed: 1 December 2012).

\footnotetext{
${ }^{141}$ See Letter from Jorge Daniel Taillant, CEDHA, to the President and Board of Directors of the World Bank Group, with carbon copy to ING Groep N.V. 3-4 (10 March 2006), available at: http://casopasteras.cedha.net/wpcontent/uploads/2011/09/letter-cedha-board-directors-march-10-2006.pdf (last accessed: 1 December 2012, summarizing protests, media reports, and legal complaints relating to the Botnia mill).
} 
In April 2006, ING abruptly announced that it was ending its involvement with Botnia. ${ }^{142}$ ING did not offer reasons for its decision, but stated that the decision was not linked to allegations of a breach of the Equator Principles. ${ }^{143}$ That being said, at least one Botnia official has implied that ING's withdrawal was motivated by the negative publicity that accompanied the allegations. ${ }^{144}$ The IFC, however, ultimately decided to finance the project after its CIS concluded that the risks posed by the paper mill were manageable on both sides of the border. ${ }^{145}$ Following consultation with NGOs, Calyon, an affiliate of EPFI Crédit Agricole, joined the IFC in financing the project. ${ }^{146}$

Argentina's protest of the mill continued; its government filed a complaint with the International Court of Justice (ICJ), alleging that Uruguay, by unilaterally approving construction of the mill, had violated bilateral treaties providing for joint management of the Uruguay River. ${ }^{147}$ The ICJ did not rule, however, until 2010, nearly two years after construction of the paper mill had completed and production had begun. It concluded that Uruguay had violated international law by constructing the mill, but refused to order

\footnotetext{
142 Letter from A. Cohen Stuart, ING Groep N.V., to J.D. Taillant, CEDHA (12 April 2006), available at: http://198.170.85.29/ING-statement-re-pulp-mill-in-Uruguay-12-April-2006.pdf (last accessed: 1 December 2012).

${ }^{143}$ Id.

${ }^{144}$ Benedict Mander, 'Green' dispute means trouble for investors at Uruguay Mills, FIN. TIMES, 10 June 2006 at 5.

145 Press Release, IFC, IFC and MIGA Board Approves Orion Pulp Mill in Uruguay: 2,500 Jobs to Be Created, No Environmental Harm (21 November 2006), available at: http://www.ifc.org (last accessed: 1 December 2012). See ECoMetrix, Inc., CUMUlative IMPACt Study, URuguay Pulp Mills (September 2006), available at: http://www.upmuruguay.com.uy (last accessed: 1 December 2012). See also AMEC, ORION BKP MILL PRE-STARTUP AUDIT 1 (September 2007), available at: http://ww.ifc.org (last accessed: 1 December 2012, which provides an update on Botnia's construction, and states that Botnia is being constructed in accordance with the CIS).
}

\footnotetext{
146 Press Release, CEDHA, Calyon to support controversial Botnia pulp mill (15 January 2007), available at: http://www.banktrack.org (last accessed: 1 December 2012).
}

\footnotetext{
147 Pulp Mills on the River Uruguay (Argentina v. Uruguay), Application Instituting Proceedings (4 May 2006),
} available at: http://www.icj-cij.org (last accessed: 1 December 2012). 
Uruguay to dismantle it. ${ }^{148}$ Argentina and Uruguay subsequently agreed to a new process for the joint monitoring of the mill's environmental and social effects. ${ }^{149}$

What is striking about the Botnia dispute is how quickly the Equator Principles faded from relevance. Instead, it was the IFC Safeguards and public international law that played a central role in guiding lenders' actions. It is likely not a coincidence that both of these regulatory frameworks feature impartial, credible enforcement mechanisms in the form of the CAO and the ICJ, respectively. Botnia also highlights the importance and the variety of roles local and national officials can play in the project finance sector, from promoting projects, to amplifying opposition to projects, to creating new regulatory frameworks to resolve disputes over projects.

Most importantly for the purposes of this article, Botnia casts further doubt on lenders' current ability to act as credible enforcers of the Equator Principles. Rather than being proactive in encouraging Botnia S.A. to comply with the Equator Principles, ING and Calyon appear to have taken their cues from other actors, namely the CAO and the IFC, respectively.

This does not mean that the Equator Principles should be abandoned. Rather, it suggests at least two ways in which the Equator Principles could be improved. First, the Equator Principles Association could establish an office equivalent to the IFC's CAO to review noncompliance complaints. ${ }^{150}$ Even if such a body is purely advisory in nature, its recommendations could (as the CAO's recommendations did) exert considerable influence over EPFIs' behavior. Second, the Equator Principles could empower local regulators by including a provision stating that borrowers would, where appropriate, fund technical assistance for local government regulators. ${ }^{151}$

${ }^{148}$ Pulp Mills on the River Uruguay (Argentina v. Uruguay), [2010] I.C.J. Rep. 14, 106.

\footnotetext{
${ }^{149}$ Press Release, Argentina, Office of the President, El acuerdo ambiental entre Argentina y Uruguay "marcará un hito", afirmó Timerman (The environmental agreement between Argentina and Uruguay "a milestone", said Timerman) (30 August 2010), available at: http://www.prensa.argentina.ar (last accessed: 1 December 2012).

${ }^{150}$ Calls for the Equator Principles to provide for an ombudsperson date back at least to 2005. See FrESHFIELDS

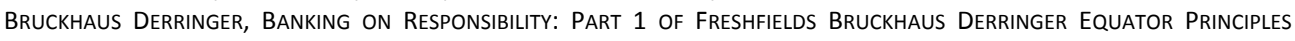
SURVEY 2005: THE BANKS 22 (July 2005), available at: http://web.archive.org/web/20100210172210/http://www.freshfields.com/publications/pdfs/practices/12057.p df (last accessed: 1 December 2012).

${ }^{151}$ See Mclnerney, supra note 2, at 175 (also proposing that local regulators be supplied with technical assistance).
} 


\section{Conclusion}

As the Equator Principles approach their tenth anniversary, it is possible to make a number of observations about lenders' performance as regulators. They have proved to be relatively effective standard setters, incorporating best practices into their rulemaking processes and into the substance of the Equator Principles. They remain well-placed to monitor compliance with the Equator Principles, given that their role as lenders already places them in a position to more generally monitor their borrowers' conduct. That being said, lenders likely should take a more active role in monitoring by carrying out on-site studies of proposed projects and the communities they are likely to affect. While at present, lenders are not well-placed to enforce the Equator Principles, the creation of an independent ombudsperson to review complaints submitted by NGOs may create a new source of pressure for lenders to take more coercive action in the face of deliberate and repeated non-compliance by borrowers. By requiring borrowers to support technical assistance for state and local government regulators, lenders may also be able to compensate for their own lack of enforcement capacity by empowering other regulators to enforce their own related standards.

This article began by presenting two contrasting views of the role private companies can play in developing and enforcing standards for the public good. The assessment of the Equator Principles carried out in this article indicates that a definitive answer to this debate is and will continue to be elusive. Different regulatory standards operate within different regimes, populated by different actors and different shared norms and principles. The makeup of these regimes, along with way in which a regulatory framework is designed, will affect a regulator's capacity and willingness to set standards and monitor and enforce compliance. In addition, the tasks associated with regulation - the setting of standards and the monitoring and enforcement of compliance - may be shared between public and private actors. To summarily conclude that private regulation and regulators are always superior to public regulation and regulators in all respects, or vice versa, would be to paper over these complexities. 